\title{
Elemental Analysis of Soil and Effluent Samples Sourced from Hermas Paint Industry, Enugwu-Ukwu
}

\author{
Ebele Joy Morah, Vincent Ishmael Egbulefu Ajiwe*, Priscilla Chinwe Okonkwo, \\ Blessing Chidimma Ikezuagu, Nkiruka Charity Eboagu, Ozioma Juliana Anekwe
}

Department of Pure and Industrial Chemistry, Nnamdi Azikiwe University, Awka, Nigeria

Email address:

ebelemorah2014@gmail.com (E. J. Morah),vaj_04@yahoo.com (V. I. E. Ajiwe)

${ }^{*}$ Corresponding author

\section{To cite this article:}

Ebele Joy Morah, Vincent Ishmael Egbulefu Ajiwe, Priscilla Chinwe Okonkwo, Blessing Chidimma Ikezuagu, Nkiruka Charity Eboagu, Ozioma Juliana Anekwe. Elemental Analysis of Soil and Effluent Samples Sourced from Hermas Paint Industry, Enugwu-Ukwu. American Journal of Applied Chemistry. Vol. 9, No. 2, 2021, pp. 49-52. doi: 10.11648/j.ajac.20210902.12

Received: April 20, 2021; Accepted: May 24, 2021; Published: June 16, 2021

\begin{abstract}
Industrial pollution by effluents is one of the major problems facing Nigerians at present and several efforts are being vigorously engaged to control it in the various industry spanning the length and breadth of the country to see that Nigerians live in a disease-free environment. Some heavy metals contained in these effluents from the industry have been found to be carcinogenic, toxic or poisonous to the environment (plants, animals and humans). This research paper investigates the heavy metal content of the effluent and soil samples in order to determine the level of toxicity and pollution by the metals to the environment. The elemental analysis of soil and effluent samples were conducted. The soil samples were sourced 2metres distance away from the discharge point of the effluent. The soil samples were digested using aqua regia for the elemental analysis for the detection of ten different metals (lead, arsenic, cadmium, chromium, calcium, zinc, sodium, mercury, iron and cobalt) using atomic absorption spectrophotometer. The values of the mean concentrations of the elements $\mathrm{Pb}, \mathrm{As}, \mathrm{Cd}$, $\mathrm{Cr}, \mathrm{Ca}, \mathrm{Zn}, \mathrm{Na}, \mathrm{Hg}, \mathrm{Fe}$ and $\mathrm{Co}$ in both the soil and effluent samples showed excessive levels above the recommended standards for WHO and NESREA with the exception of $\mathrm{Na}, \mathrm{Ca}$ and $\mathrm{Zn}$. This indicates that the effluent was discharged without proper treatment. It is therefore recommended that adequate monitoring should be done through aggressive supervision on effluent treatment before discharge. Local raw materials such as activated carbon, coal, rice husk, saw dust and clay should be employed in the treatment of the effluent as they are readily available and cost- saving.
\end{abstract}

Keywords: Elemental Analysis, Soil Samples, Effluent Samples, Hermas Paint

\section{Introduction}

Paint is a fluid basically containing a solid colouring material, which is pigment and the liquid matter, which is the vehicle, in suspension. The origin of paint was the result of the act of the Egyptian decorating mummies about 10000 years ago $[1,2]$.

The paint industry is a polymer by virtue of the fact that some of raw materials employed in paint manufacture are polymeric materials. The raw materials/ additives include resins, pigments, extenders, driers, plasticizers, dispersants, biocide, conductive polymers, binders, polymer-coated steel, bio-polymers e.t.c. [2, 3].

Effluents are wastewater: treated, partially treated or untreated which reduces the wholesomeness and quality of the environment $[4,5]$. Effluents may be classified as municipal, industrial, agricultural, institutional and research laboratory effluents [6, 7]. Effluents from paint industry is said to be one of the sources which contributes a greater percentage of the effluent/ wastewater which pollutes the environment.

Effluents from domestic or from an agricultural processing activity can be reused as source of water for irrigation in arid and semiarid regions where there is limited availability of water development. Effluents from various sources could be recycled to generate potable water from municipal while the organic residue resulting from such treatment are converted to fertilizer for crop production $[7,4,8]$. Effluents rich in nutrients, when 
discharged into farmlands could help boost the fertility of the soil in addition to development of shells and bones in aquatic animals by those rich in calcium and magnesium [7]. On the other hand, effluent rich in nutrients may lead to eutrophication/ over-enrichment in the receiving waters [4]. In addition, industrial, effluents results in health disaster and cause adverse effect on crop growth due to decreased soil permeability and ground water contamination [9]. Due to absorptive properties of the soil, some pollutants such as $\mathrm{Cu}, \mathrm{Pb}$ and $\mathrm{PCBs}$ stay long in the soil and affect food crops grown on such polluted soil for centuries [10]. Some heavy metals contained in these effluents (either in free form or adsorbed in the suspended solids) from the industries have been found to be carcinogenic $[11,12]$ while other chemicals equally present are poisonous depending on the dose and exposure duration [13]. These heavy metals are not only poisonous but also found to be toxic to aquatic life and may result in food contamination [5, 14]. Owing to this, contamination of water and food has remained serious hazards to humans and the environment [15].

Heavy metals are mainly used as pigments and blotters in the paint. The heavy metals in paint effluent commonly include $\mathrm{Cd}, \mathrm{Pb}, \mathrm{Cu}, \mathrm{Ni}$ and $\mathrm{Co}$. these heavy metals are not biodegradable and their presence in streams and lakes leads to bioaccumulation in living organisms, causing health problems in animals, plants and human beings [16, 17] due to carcinogenicity, mutagenicity, teratogenicity and high acute toxicity [8, 12]. People are exposed to heavy metals through inhalation, water and food ingestion [18]. Due to absorptive properties of the soil, some pollutants such as $\mathrm{Cu}, \mathrm{Pb}$, and PCBs stay long in soils and foods crops grown on such polluted soils may be affected for centuries; $\mathrm{Pb}$ readily accumulates in the humus- rich surface area of the soils due to its complexity with organic matter and it was reported to be the least mobile heavy metals in soils under reducing and non- reducing conditions [10, 13].

Heavy metals also find their way into various plants and are deposited in seeds, fruits, leaves, tubers and even roots. On consumption of these plants, the metals gradually get accumulated in the body of the organism until a certain level (tolerance level) is exceeded when the organism begins to show changes in morphology and then morbidity and mortality may result. Human consume metallic elements through both food and water. Some heavy metals are found in living tissues and are essential to human life. The heavy metals such as manganese, cobalt, molybdenum, copper and zinc have been linked to human growth, development, achievement and reproduction. However, when their concentrations are too high, they become toxicant within relatively short period of time and are nonessential for human health [19-21].

The purpose of this research is to investigate some of the heavy metal content of the soil and effluent samples so as to ascertain their level of toxicity and pollution to the environment.

\section{Method}

\subsection{Sample Collection}

The sample soils were collected from Hermas Paint Industry, Enugwu-ukwu, Anambra. These were collected at one-month interval from August to October, 2014. About $2 \mathrm{~kg}$ of each soil samples was collected 2 metres away from the discharge point after digging into the soil about $15 \mathrm{~cm}$ deep at the three different points (2 metres forward, 2 metres towards the right and 2metres towards the left) for each month. The soils samples were stored in black polythene bags from where they were taken for analysis.

The sample effluents were collected from the discharge point of the same industry for three sampling periods such as August, September and October, 2014. The effluents stored in high density polyethylene bottles were carried in an ice box.

\subsection{Sample Preparation}

\subsubsection{Digestion of Soil Samples for AAS Analysis}

The soil samples were digested for AAS (Atomic absorption Spectrophotometric) analysis.

1 gramme of each of the soil samples was digested using (1:1) aqua regia and oven dried at $105^{\circ} \mathrm{C}$ for one and half hours and cooled. $10 \mathrm{ml}$ of saturated solution of ammonium oxalate was then added to the oven dried content of the conical flask placed in an oven and further heated until the content becomes colourless. The cooled colourless content was made up to $100 \mathrm{ml}$ in a volumetric flask with distilled water and then filtered to obtain a filtrate used for the AAS analysis using an atomic absorption spectrophotometer (model: AA280) [22-25].

\subsubsection{Sample Effluent Preparation for AAS analysis}

The sample effluents stored in a HDPE bottles were taken from the refrigerator maintained at $4{ }^{\circ} \mathrm{C}$ and atomic absorption spectrophotometer (AAS) (Model AA 280) was used to determine the concentrations of the metal ions in the samples.

\section{Results}

The results of the analyses are shown in tables 1 and 2 below. The average metal levels of the effluent and soil samples were compared with the World Health Organization (WHO) and Nigerian Environmental Standards and Regulations (NESREA) specifications. This is carried out in view to assessing the effluent treatment and its impact on the environment.

\section{Discussion}

The results of the analysis are shown in tables 1 and 2. A Comparison of the mean calcium concentrations from both the effluent and the soil samples showed that the mean level of calcium in the sample effluents was higher than that of the sample soils. This could be attributed to the fact that calcium 
was leached into the soil. Calcium is needed for the body growth and strong bones. The lower mean calcium levels in the samples limit the formation of excessive scales. The mean sodium levels contained in the samples were below the acceptable standard for the WHO. As a result, no adverse effect was observed. High sodium concentration leads to poor soil permeability while low sodium concentration in water destroys certain diseases. A comparison of the heavy metal concentrations of both the sample soils and effluents showed the following; with the exception of the mean levels of the heavy metals such as $\mathrm{Zn}$, the mean level of the other heavy metals in both the sample soils and effluents showed the following: with the exception of the mean levels of the heavy metal such as $\mathrm{Zn}$, the mean levels of the other heavy metal concentrations of both the sample soils and effluents all exceeded the recommended levels of NESREA and WHO. This has detrimental effect on human health, plant and animal due to bioaccumulation of the heavy metals which are nonbiodegradable. Zinc in trace level is beneficial for body growth while iron plays a special role in respiration. Mercury is a cumulative poison which causes nerve damage, hepatitis, anaemia and even death. Arsenic may cause cancer. Cadmium could lead to lung cancer and bone defects. Lead is a cumulative poison which causes brain damage and even death. Most cases where the mean levels of the heavy metals in the sample effluents were greater than those of the sample soils could be that the metals were leached into the soil by rainfall.

Table 1. Average metal level in milligram per gramme ( $\mathrm{mg} / \mathrm{g})$ of soil samples.

\begin{tabular}{|c|c|c|c|c|c|c|}
\hline Parameter & August 2014 & September 2014 & October 2014 & Mean $\pm \%$ RSD & WHO Limit & NESREA Limit \\
\hline $\mathrm{Cd}(\mathrm{mg} / \mathrm{g})$ & 0.12 & 0.17 & 0.25 & $0.18 \pm 36.43$ & 0.01 & 0.1 \\
\hline $\mathrm{Co}(\mathrm{mg} / \mathrm{g})$ & 1.16 & 0.44 & 0.34 & $0.65 \pm 68.83$ & 0.05 & 0.5 \\
\hline $\mathrm{Fe}(\mathrm{mg} / \mathrm{g})$ & 0.54 & 0.46 & 1.28 & $0.76 \pm 59.49$ & 0.3 & 2.0 \\
\hline $\mathrm{Na}(\mathrm{mg} / \mathrm{g})$ & 1.40 & 4.73 & 15.07 & $7.06 \pm>100$ & 200 & 200 \\
\hline $\mathrm{Pb}(\mathrm{mg} / \mathrm{g})$ & 0.06 & 0.33 & 0.25 & $0.21 \pm 66.06$ & 0.05 & 0.1 \\
\hline $\mathrm{Hg}(\mathrm{mg} / \mathrm{g})$ & 0.62 & 0.60 & 0.68 & $0.63 \pm 6.64$ & 0.001 & 0.01 \\
\hline As $(\mathrm{mg} / \mathrm{g})$ & 0.61 & 0.76 & 0.53 & $0.63 \pm 18.47$ & 0.05 & 0.1 \\
\hline $\mathrm{Ca}(\mathrm{mg} / \mathrm{g})$ & 0.76 & 0.69 & 3.40 & $1.62 \pm 95.35$ & 100 & 200 \\
\hline $\mathrm{Cr}(\mathrm{mg} / \mathrm{g})$ & 1.16 & 0.44 & 0.34 & $0.65 \pm 68.83$ & 0.05 & 0.01 \\
\hline
\end{tabular}

Table 2. Average metal level in milligram per litre (mg/l) of effluent samples.

\begin{tabular}{|c|c|c|c|c|c|c|}
\hline Parameter & August 2014 & September 2014 & October 2014 & Mean $\pm \%$ RSD & WHO Limit & NESREA limit \\
\hline $\mathrm{Cd}^{2+}(\mathrm{mg} / \mathrm{l})$ & 0.41 & 0.20 & 0.24 & $0.28 \pm 39.85$ & 0.1 & 0.1 \\
\hline $\mathrm{Co}^{2+}(\mathrm{mg} / \mathrm{l})$ & 0.56 & 0.59 & 0.26 & $0.47 \pm 45.53$ & 0.05 & 0.5 \\
\hline $\mathrm{Fe}^{3+}(\mathrm{mg} / \mathrm{l})$ & 8.42 & 0.52 & 0.64 & $3.19 \pm>100$ & 0.3 & 2.0 \\
\hline $\mathrm{Na}^{+}(\mathrm{mg} / \mathrm{l})$ & 8.48 & 5.36 & 3.84 & $5.89 \pm 40.16$ & 200 & 200 \\
\hline $\mathrm{Pb}^{2+}(\mathrm{mg} / \mathrm{l})$ & 4.05 & 0.16 & 0.95 & $1.72 \pm 84.53$ & 0.05 & 0.1 \\
\hline $\mathrm{Hg}^{2+}(\mathrm{mg} / \mathrm{l})$ & 1.84 & 0.31 & 0.04 & $0.73 \pm>100$ & 0.001 & 0.01 \\
\hline $\mathrm{As}^{3+}(\mathrm{mg} / \mathrm{l})$ & 0.83 & 0.37 & 0.13 & $0.44 \pm>80.85$ & 0.05 & 0.1 \\
\hline $\mathrm{Ca}^{2+}(\mathrm{mg} / \mathrm{l})$ & 3.44 & 7.92 & 4.19 & $5.18 \pm 46.32$ & 100 & 200 \\
\hline $\mathrm{Cr}^{3+}(\mathrm{mg} / \mathrm{l})$ & 3.98 & 0.67 & 1.14 & $1.93 \pm 92.79$ & 0.05 & 0.01 \\
\hline
\end{tabular}

From the results shown in tables 1 and 2, the heavy metals occurred in trace amounts while $\mathrm{Na}$ and $\mathrm{Ca}$ occurred in appreciable amounts. There is no definite variation pattern in the level of the metals. The lower level of iron in the soil shows that the iron (iii) in the effluent must have been converted to soluble iron (iii) in the soil under reducing anaerobic condition.

\section{Conclusions}

The elemental analysis of soil and effluent samples from Hermas paint industry Enugwukwu has been carried out successfully. The mean concentrations of the heavy metals such as cadmium, cobalt, iron, lead, mercury, arsenic, zinc and chromium analysed in the sample soils and effluents showed excessive levels above the recommended standards for WHO and NESREA. This is an indication of pollution which means that the effluent was discharged without proper treatment. Heavy metals are toxic metals which pollute water bodies. They originate from anthropogenic sources such as industrial effluents and mining ores. Humans are also at risk of consuming contaminated drinking water. The concentration of the metals in the sample was monitored in order to estimate the extent of pollution. Most of the metals are detrimental to human health, aquatic life and plants. Heavy metals are toxic to coastal life even at concentration as low as $0.5 \mathrm{ppm}$. For instance, the skin absorption of mercury as well as inhalation of its dust or fume is toxic or carcinogenic. Methyl mercury causes the miniamatex disease. Cadmium causes changes in the cells and results in offspring that are detrimentally different from their parents. Also, $\mathrm{Hg}^{2+}, \mathrm{Pb}^{2+}$ and $\mathrm{Cd}^{2+}$ bind to sulphur in enzyme proteins and such enzymes cannot function properly and the hosts suffer. Arsenic forms complex with enzymes. The sinks for heavy metals include soil, aquatic environment, body of animals and crops. It is therefore recommended that adequate monitoring should be ensured to prevent the bioaccumulation of heavy metals which could be detrimental to human health. 


\section{Acknowledgements}

The authors are grateful to Hermas paint industry, Enugwu-ukwu, Anambra State for providing the raw material used in the monitoring and to the IBETO, Nnewi, Anambra State as well as National Research Institute of Chemical Technology, Samaru, Zaria Kaduna for analyzing the sample soils and effluents.

\section{References}

[1] Onyenekenwa, C. E. (1999); A Guide for the Paint Maker, $1^{\text {st }}$ Ed., Computer Edge Publishers, Enugu pp 3-10.

[2] Berger, S. P (1998): The Paint Manufacturing Process. No. 1 pp 1-5.

[3] Ibemesi J. A (1991); Paint Technology (Unpublished). Department of Industrial Chemistry, University of Nigeria, Nsukka pp 27-38.

[4] Ezeonu, E. (2003); Pollution and Industrial Wastes Management, Chemistry in Nigeria. 2 (2): 17-20.

[5] Onuegbu, T. U; Ajiwe, V. I. E; Arinze R. U and Okoye, L. O. (2007); Analysis of Untreated Effluents from Guinness Brewery in Nigeria. Journal of Applied Sciences. 10 (4): 7466-7473.

[6] Womach, J.(2005); Water Supply and Sanitation in the United States. Congressional Research Service Document. CWA Sections 301, 306 and 307.

[7] Sangodeyin, A. Y. (1995); Characteristics and Control of Industrial Effluent-generating Pollution. Journal of Environmental Management and Health. 6 (4): 15-18.

[8] Ezeonu, E. (2005); Chemistry and Nigeria Economy, the Proceedings of the $28^{\text {th }}$ International Conference of the Chemical Society of Nigeria.

[9] Ajiwe V. I. E., Mbeledogu, S. C; Ajiwe, C. C and Nnabuenra, H. O. (2008); Analysis of Micro and Macro Elements in Nnamdi Azikiwe University Soil, Anachem Journal, 3 (1): 434-438.

[10] A Journal of Effluent-monitoring for the shell Petroleum Development Company of Nigeria Ltd, East (2004).

[11] Isoa, U. S. (2000); Toxicological Aspect of Heavy Metal Pollution. Pearson Press Ltd. India, pp 10-15.
[12] Malakootian, M., Almasi A., and Hossaini, H. (2008). Pb and Cd Removal from Paint Industries Effluent using Wood Ash. International Journal of Environmental Science Technology, 5 (2): $217-222$.

[13] World Health Organization (WHO) (1992) Health Hazard of Human Environment.

[14] Igbokwe, P. K; Nwabanne, J. T. and Okolomike, R. O. (2008); Adsorption of Lead and Cadmium from Waste Water using Coconut Shell Activated Carbon, Anachem Journal, 2 (1): 237-244.

[15] Ajiwe V. I. E (2009); Handbook of Environmental Chemistry, pp 4-11.

[16] Needlemana, H. L and Berlinger, D.(2001); Studies of Lead Exposure and the Developing Central Nervous System: A Reply to Kanfman. Arah. Clinc. Neuropsych. 16 (4): 359-374.

[17] Howard, H. M. D, M. P. H, S. D (2002). Human Health and Heavy metal, Exposure. MIT publication.

[18] Abdus-salam, N. and Adekola, F. A (2005). The Influence of $\mathrm{PH}$ and Adsorbent Concentration on Adsorption of Lead and Zinc on a Natural Geothite. African journal of Science Technology, 6: 55-66.

[19] Okonkwo, E. M. and Eboatu, A. N (1999); Environmental Pollution and Degradation, Book 2, Onis Excel Publishing Ltd. Zaria. pp 2-81, 113-140.

[20] Federal Environmental Protection Agency (FEPA) (1991): National Guidelines and Standards for Industrial Effluents, Gaseous Emissions and Hazardous Waste Management in Nigeria. Federal Environmental Protection Agency, Lagos.

[21] Goudie, A.(1994); The Human Impact on the Natural Environment: the M. I. T press. pp. 116-119.

[22] Ademoroti, C. M. A (1998); Standard Methods for Water and Effluent Analysis, Foludex Press Ltd. Ibadan pp 20-121.

[23] Williams, D. H and Fleming, I. (2000); Spectroscopic methods in Organic Chemistry, $3^{\text {rd }}$ Edition, McGraw-Hill Book Company (UK) Ltd. pp 35-73.

[24] Akpuaka, M. U. (2009). Essentials of Natural Products Chemistry; Mason Publishers, Enugu Nigeria. pp 94-96.

[25] Mukhopadhyay, R. and Datta, S.(2007); Environmental Chemistry, New Age International Ltd. Publishers, New Delhi, pp 512-526. 